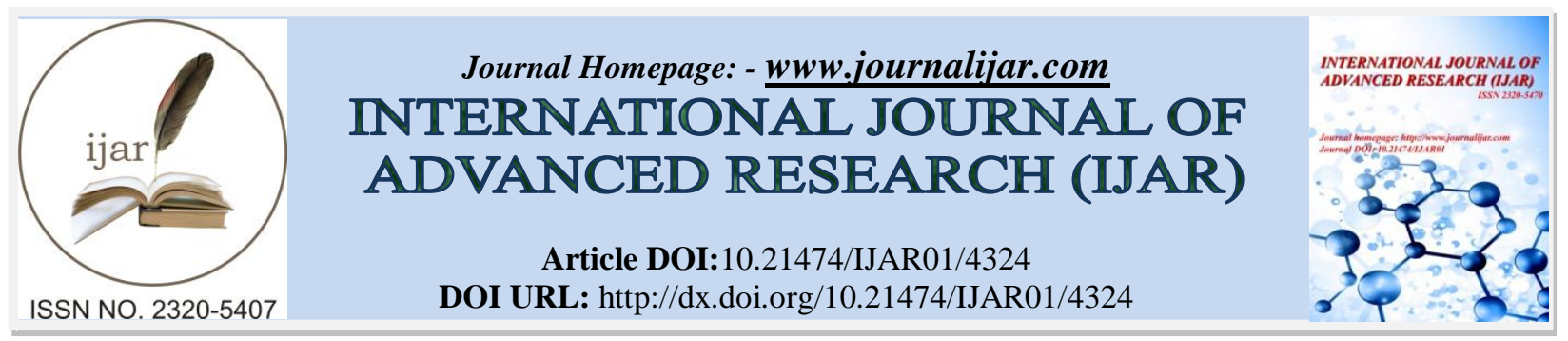

\title{
RESEARCH ARTICLE \\ GENETIC VARIATION IN TASTE SENSITIVITY OF PHENYLTHIOCARBAMIDE AMONG FOUR VARNA POPULATION OF HINDU RELIGION OF LUCKNOW DISTRICT, UTTAR PRADESH (INDIA).
}

Vibha Devi Bajpai.

Department of Anthropology, University of Lucknow, U.P. India.

\section{Manuscript Info}

...........................

\section{Manuscript History}

Received: 24 March 2017

Final Accepted: 29 April 2017

Published: May 2017

Key words:-

Phenylthiocarbamide, Gene frequency,

Heterozygosity, Varna, Lucknow.

\section{Abstract}

The ability to taste phenylthiocarbamide (PTC), a bitter chemical has long been known to be a bimodal autosomal trait inherited in a simple Mendelian recessive pattern which is being widely used for both genetic and anthropological studies. The frequency of taster and nontaster alleles is found to vary in different population. This study was taken to determine PTC taste sensitivity among Brahmin, Kshatriya, Vaishya and Shudra population of Lucknow and discussed it with reference to genetic variability. Unrelated individuals of both sexes belonging to four Varna populations were randomly selected and screened using serial dilution method of Harris and Kalmus (1949). The phenotypic frequency for PTC taste ability varies between four populations ; Brahmin (79\%) were observed with highest taster frequency while Vaishya (72\%) and Shudra (73\%) had the lowest taster frequency. The tester frequency of four population showed that the percentage of tester frequency more frequent than that of the nontasters. Kshatriya (7.25) and Brahmin (6.98) population showed highest PTC mean threshold while Shudras (5.86) had the least. In inter- Varna differences in terms of $X^{2}$ Value 0.1622 is the highest value in comparison of Brahmin and Vaishya whereas 0.0034 is the lowest value in the comparison of Vaishya and Shudra Varna population.

\section{Introduction:-}

Variation in taste sensitivity to the bitter compound phenylthiocarbamide (PTC) is one of the best known Mendelian traits in human populations, ranking alongside eye colour and blood types in the canon of classic examples. Much of PTC's appeal arises from the fact that it is nearly impossible to guess one's phenotype until explicitly tested, yet, when tested, the phenotype is so stricking as to be amusing. This property is important, particularly in education, because it can spice up lessons on inheritance. Less obvious, especially today, is PTC's appeal as an easily typed yet highly informative genetic marker. It was this aspect of the trait that made PTC an important instrument in the earliest efforts to dissect the human genome (Crow and Dove, 2006).

About 66 years ago, A. L. Fox, a Du Pont chemist, reported a startling accidental discovery (Anonymous 1931, Fox 1932). Boyd (1950) describes the event: 
Dr. A. L. Fox had occasion to prepare a quantity of phenylthio-carbamide. As he was placing this compound in a bottle some of it was dispersed into the air as dust. Thereupon another occupant of the laboratory complained of the bitter taste of the dust. This surprised Fox, who being much closer to the scene of operations had of course inhaled more of the dust, but had perceived no taste. He was so positive that the stuff was tasteless that he went so far as to taste some of the crystals directly, finding them as tasteless as chalk. Nevertheless the other chemist was convinced the substance was bitter and was confirmed in this impression when he in turn tasted the crystals and found them to be intensely bitter. Naturally, a lively argument arose. In an attempt to settle it, the two chemists called in various other laboratory workers, friends and other people with whom they could establish contact. Some people declared the substance was tasteless and some again found it bitter.

The threshold at which people can taste phenylthiocarbamide (PTC) is bimodal, and some people are tasters and others are non-tasters (Hartmann, 1939; Riddell and Wybar 1944; Kalmus 1952). Family and twin studies suggest this trait is inherited as a Mendelian recessive, with two alleles typically represented as $\mathrm{T}$ and $\mathrm{t}$, with $\mathrm{T}$ representing the 'tasting' allele and t the 'non-tasting' allele (Blakeslee 1931, Snyder 1931, Blakeslee 1932, Levit and Soboleva 1935, Lee 1937, Rife 1938, Hogben 1946, Matsunaga and Tsuji 1957, Merton 1958, Pons 1960, Kaplan and Fischer 1965, Martin 1975, Rao and Morton 1977, Forrai and Bankovi 1984, Whissell-Buechy 1990b). The evidence for a genetic component underlying the PTC tasting ability is so strong that it was once used in paternity tests before DNA markers were available (Cardullo and Holt, 1951). The ability to taste PTC is listed as a genetic trait (McKusick 1995) and has been referred to as an 'honorary blood group'.

Opening any genetics or anthropology journal published after 1930, one can hardly find an issue without a paper on the genetics of PTC. Indeed, the taste-blindness of PTC is perhaps the most studied trait in human genetics, second only to the ABO blood group system. However, almost 70 years after Fox's discovery, the genetic study of PTC ability has not advanced at the same rate as the genetics of other inherited phenotypes. The gene has not been characterized.

PTC tasting ability is not just one of many seemingly innocuous human traits (such as tongue-rolling or arm-folding) that are interesting but not worth pursuing the underlying genetic variability. PTC blindness is reportedly associated with food preferences and several diseases, especially disorders of thyroid metabolism. Characterization of the PTC gene would provide a powerful tool to further examine and delineate each of these associations. The exact mechanism of taste transduction is still poorly understood and has lagged behind the biology of other sensory modalities such as auditory, olfactory, mechanioreception and photoreception. The characterization of the PTC gene would provide an opportunity to investigate gustatory function, as interface where 'physiology and psychology meet' (Adrian, 1963), (Guo and Reed, 2001).

\section{Area and People:-}

The present study is conducted among the four Varna population of Lucknow district of Uttar Pradesh. Lucknow is the largest and most developed city in north India after Delhi. It is situated in the middle of the Gangetic plain. It is located at 26.84 latitude and 80.92 longitude and situated at elevation 126 meters above of sea level. The areas selected for field work from Lucknow were Gomti Nagar, Alambagh, Aliganj, Bakshi Ka Talab, Telibagh, Chowk, Qaiserbagh, Aminabad and Rajaji Puram.

\section{Methodology:-}

The data was collected from January 2010 to June 2010 for testing PTC taste ability in four Varna population of Lucknow district of Uttar Pradesh. Four hundred individuals were randomly selected from four Varna population viz; Brahmin, $(n=100)$, Kshatriya $(n=100)$, Vaishya $(n=100)$ and Shudra $(n=100)$. In which 50 percent male and 50 percent female individuals were selected.

Taste Sensitivity to PTC was ascertained using the serial dilution method by Harris and Kalmus (1949). A stock solution containing $0.13 \%$ phenylthiocarbamide was prepared in distilled water and serial dilutions were made up to the number thirteen. The least diluted solution was numbered as dilution number 14 and the most diluted solution was numbered as dilution number 1 . If an individual could not taste any solution including 14 , then he/she was designated as non-taster. The experiment was commenced with the weakest PTC solution in the order of increasing concentrations. Threshold level for PTC were then recoreded for males and females of each population. 
Statistical and Gene frequency Analysis:-

Chi- square $\left(\mathrm{X}^{2}\right)$ test is used for statistical analysis:

$X^{2}=\sum$ (Observed frequency- Expected frequency $)^{2}$

Expected Frequency

Genotype and allele frequencies for each population were calculated by Hardy-weinberg method and heterozygosity was determined.

\section{Result and Discussion:-}

The data on four Varna populations in terms of taster and non-tasters has been presented in Table 2. The population belonging to both the sexes exhibit a similar pattern of phenotypic variation in so far as the tasting ability is concerned, confirming that no sexual dimorphism is indicated as regards this trait .The modal value is noted at solution no. 9 in case of Brahmin, Kshatriya and Shudra whereas at solution no. 8 in case of Vaishya. Proportion of tasters is higher in case of females in each Varna likewise the proportion of the non-tasters is higher in case of males. It is further noted that variation in the proportion of tasters and non-tasters is of higher order in Brahmin and Vaishya whereas least exhibited by Brahmin and Kshatriyas.

Table-1: TastethresholdbyageandsexamongfourVarnasofLucknow

\begin{tabular}{|c|c|c|c|c|c|c|c|c|c|c|c|c|c|c|c|c|c|c|c|}
\hline \multirow{2}{*}{$\begin{array}{l}\text { Population } \\
\text { Group }\end{array}$} & \multirow[t]{2}{*}{$\mathbf{S} \quad \mathbf{e} \quad \mathbf{x}$} & \multirow[t]{2}{*}{ No } & \multirow{2}{*}{\multicolumn{2}{|c|}{$\begin{array}{l}\text { Non- } \\
\text { Taster: }\end{array}$}} & \multicolumn{14}{|c|}{ Phen y l hiocarbarnidesolutionnumber } & \multirow{2}{*}{$\begin{array}{l}\text { M e a n } \\
\text { Threshold }\end{array}$} \\
\hline & & & & & 1 & 2 & 3 & 4 & 5 & 6 & 7 & 8 & 9 & 10 & 11 & 12 & 13 & 14 & \\
\hline \multirow[t]{3}{*}{ Brahmin } & $\mathrm{M}$ a $1 \mathrm{e}$ & $\begin{array}{ll}5 & 0\end{array}$ & 1 & & 1 & 2 & 4 & 1 & 3 & 4 & 6 & 7 & 6 & 3 & 1 & 1 & - & - & 6.79 \\
\hline & Female & $\begin{array}{ll}5 & 0\end{array}$ & 1 & & 2 & 2 & 2 & 1 & 4 & 3 & 3 & 4 & 10 & 9 & - & - & - & - & 7.17 \\
\hline & To t a 1 & 100 & 2 & & 3 & 4 & 6 & 2 & 7 & 7 & 9 & 11 & 16 & 12 & 1 & 1 & - & - & 6.98 \\
\hline \multirow[t]{3}{*}{ Kshatriya } & $\mathrm{M}$ a $1 \mathrm{e}$ & $\begin{array}{ll}5 & 0\end{array}$ & 1 & & 1 & 2 & 4 & - & 2 & 3 & 6 & 5 & 7 & 2 & 3 & 2 & - & - & 7.21 \\
\hline & Female & $\begin{array}{ll}5 & 0\end{array}$ & 1 & & 2 & 1 & 3 & 1 & 2 & 4 & 6 & 6 & 7 & 4 & 2 & 1 & 1 & - & 7.27 \\
\hline & Tot a 1 & 100 & 2 & & 3 & 3 & 7 & 1 & 4 & 7 & 12 & 11 & 14 & 6 & 5 & 3 & 1 & - & 7.24 \\
\hline \multirow[t]{3}{*}{ V a is hy a } & $\mathrm{M}$ a $1 \mathrm{e}$ & $\begin{array}{ll}5 & 0\end{array}$ & 1 & 4 & 2 & 1 & 1 & - & 1 & 5 & 7 & 9 & 8 & 1 & 1 & - & - & - & 7.11 \\
\hline & Female & $\begin{array}{ll}5 & 0\end{array}$ & 1 & 4 & 3 & 2 & - & 2 & 5 & 2 & 9 & 8 & 4 & 1 & - & - & - & - & 6.25 \\
\hline & $\mathrm{T}$ ot a $\mathrm{l}$ & 100 & 2 & 8 & 5 & 3 & 1 & 2 & 6 & 7 & 16 & 17 & 12 & 2 & 1 & - & - & - & 6.68 \\
\hline \multirow[t]{3}{*}{$\mathrm{Shudra}$} & $\mathrm{M}$ a $1 \mathrm{e}$ & $\begin{array}{ll}5 & 0\end{array}$ & 1 & 5 & 2 & 2 & 1 & 4 & 2 & 6 & 10 & 4 & 3 & 1 & - & - & - & - & 6.00 \\
\hline & Female & $\begin{array}{ll}5 & 0\end{array}$ & 1 & 2 & 3 & 2 & 3 & 1 & 4 & 7 & 9 & 8 & 1 & - & - & - & - & - & 6.00 \\
\hline & $\mathrm{T}$ o t a 1 & 100 & 2 & & 5 & 4 & 4 & 5 & 6 & 13 & 19 & 12 & 4 & 1 & - & - & - & - & 5.86 \\
\hline
\end{tabular}

The data on taster and non-tasters was studied for mean threshold value (Table - 1). It is noted to be slightly higher in females as compared to the males in Brahmin and Kshatriyas, whereas in Vaishyas the mean threshold is high in males. On pooling the male and female of each group it becomes clear that the proportion of mean tasters is slightly lower in Shudras (5.86) and slightly higher in Kshatriya (7.24). The phenotype distribution in terms of tasters and non-taster and their relative gene frequency have been presented in Table -2 . 
Table 2:-Phenotypic percentage and gene frequencies of tasters and non-tasters within four Varnas of Lucknow

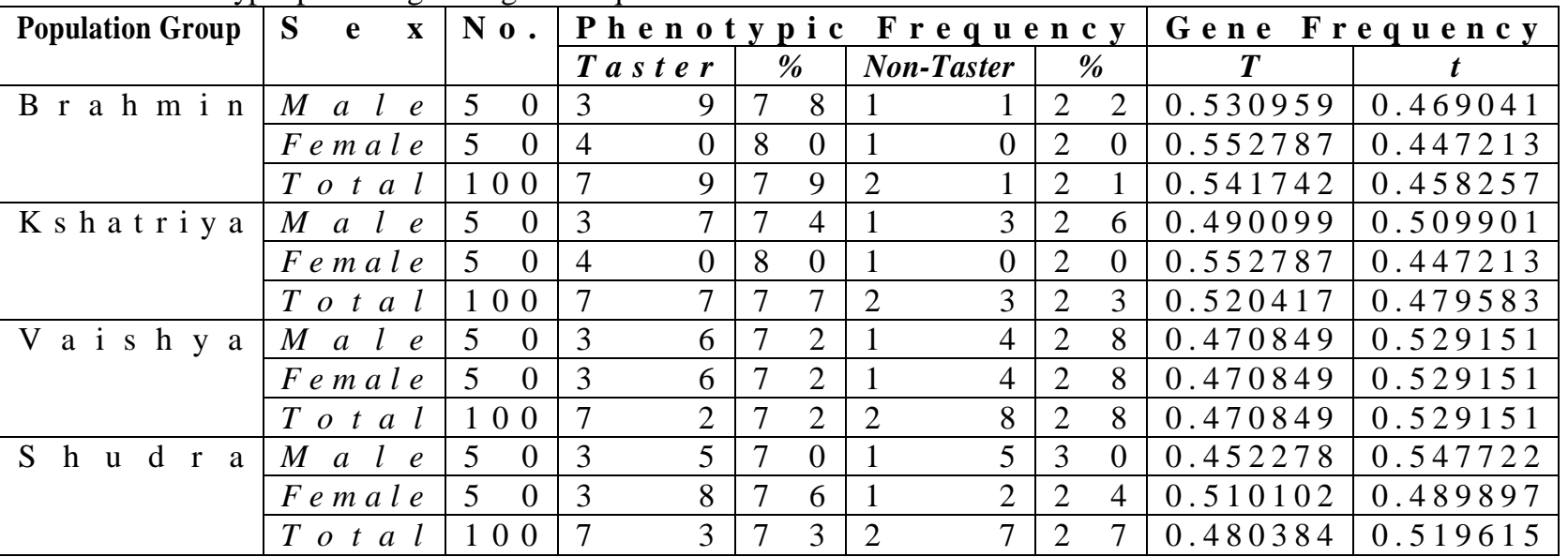

$\mathrm{T}$ and $\mathrm{t}$ are dominant and recessive alleles respectively.

The statistical evaluation of the four Varna populations in terms of the distribution of tasters and non-tasters clearly indicates that there is not significant variation at inter-Varna level. This means that in so far as the ability to taste solution of PTC is concerned the four Varnas to the same pattern of the phenotype variation and may be pooled as a single population for purposes of the working out the inter Varna variability with other populations of the states (Table 4).

Table 3:-Heterozygosity and homozygosity in terms of PTC tasting ability

\begin{tabular}{|c|c|c|c|c|c|c|c|c|c|}
\hline \multirow[t]{2}{*}{ Populat } & \multirow[t]{2}{*}{$\begin{array}{lll}\mathbf{S} & \mathbf{e} & \mathbf{x}\end{array}$} & \multicolumn{2}{|c|}{ Dominant Homozygous } & \multicolumn{2}{|c|}{ Heterozyous } & \multicolumn{4}{|c|}{ Recessive Homozygous } \\
\hline & & $T$ & $\%$ & 2 & $\%$ & & & & \\
\hline \multirow[t]{3}{*}{ B r a h m i n } & $M a l e$ & 0.281917 & 28.19 & 0.498083 & 49.80 & 0.219999 & & 0 & 0 \\
\hline & Female & 0.305573 & 30.55 & 0.494427 & 49.44 & 0.199999 & 20 & & 0 \\
\hline & $T$ o $\quad$ t $\quad \boldsymbol{a} l$ & 0.293484 & 29.34 & 0.496514 & 49.65 & 0.209999 & 2 & 0 & 0 \\
\hline \multirow[t]{3}{*}{ Kshatriya } & $M a l e$ & 0.240197 & 24.01 & 0.499803 & 49.98 & 0.259999 & 26 & 0 & 0 \\
\hline & Female & 0.305573 & 30.55 & 0.494427 & 49.44 & 0.199999 & 20 & & U \\
\hline & $T$ o $\quad$ t $\quad \boldsymbol{a} l$ & 0.270 & 27.08 & 0.499166 & 49.91 & 0.229999 & 23 & & 0 \\
\hline \multirow[t]{3}{*}{ V a i s h y a } & $M a l e$ & 0.221698 & 22.16 & 0.498300 & 49.83 & 0.280000 & 28 & & 0 \\
\hline & Female & 0.221698 & 22.16 & 0.498300 & 49.83 & 0.280000 & 28 & 0 & 0 \\
\hline & $T$ o $\quad t \quad a l$ & 0.221698 & 22.16 & 0.498300 & 49.83 & 0.280000 & 28 & 0 & 0 \\
\hline \multirow[t]{3}{*}{$\begin{array}{llllll} & h & \text { u } & d & \mathbf{r} & \mathbf{a}\end{array}$} & $M a l e$ & 0.204555 & 20.45 & 0.495445 & 49.54 & 0.299999 & & & 0 \\
\hline & Female & 0.260204 & 26.02 & 0.499794 & 49.97 & 0.239999 & 24 & & 0 \\
\hline & $T$ Tot $t$ a $l$ & 0.230768 & 23.07 & 0.499229 & 49.92 & 0.269999 & 27 & 0 & 0 \\
\hline
\end{tabular}

$\mathrm{T}$ and $\mathrm{t}$ are dominant and recessive alleles respectively.

The observed slight variation of the modal value in four Varnas needs to be examined in terms of the food habits of these populations.This would help in demonstrating whether the trends of variability are genetical or just a superficial difference owing to the sharp perception of solutions by the taste buds.

Table 4:-Inter-Varna variation with respect of PTC on employing $\chi^{2}$ test in the four Varna populations

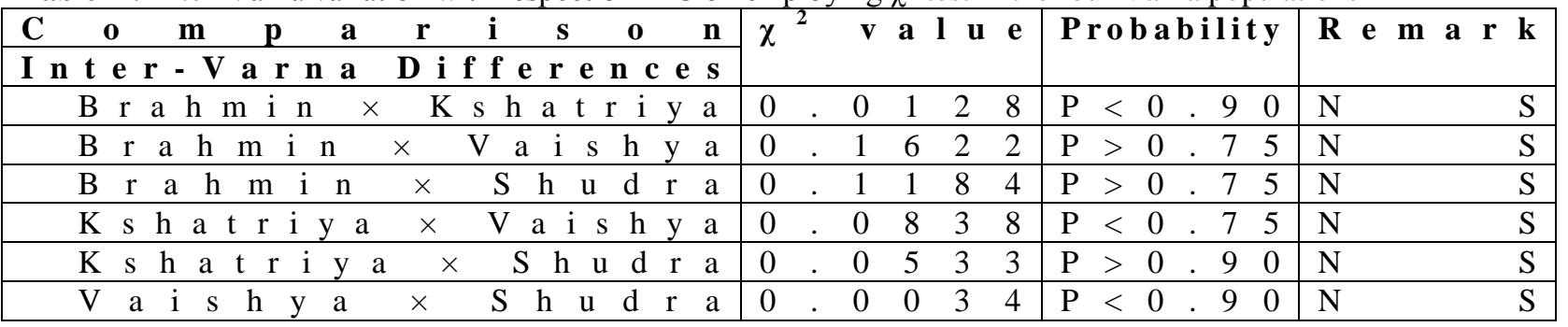

Thus in respect of taster factor, all the populations of four Varnas namely Brahmin, Kshatriya, Vaishya and Shudra 
are not distinguishable and present similar trends and they all are homogenous (Table 3).

\section{References:-}

1. Adrian E. 1963. Opening address In: Zoottermany, editor. Olfaction and taste. New York: Macmillan; pp. 1-4.

2. Agarwal, H. N. 1966. A study on ABO blood groups, PTC taste sensitivity, sickle cell trait and middle phalangeal hair among the Burmese immigrants of Andaman Islands. East. Anthrop., 19: 107-116.

3. Agnihotri, V. 1996. Demo and morphogenetic study of five endogamous groups of U.P. Brahmins.

4. Bhalla, V. 1972. Variations in taste threshold for PTC in populations of Tibet and Laddakh. Hum. Hered., 22: 453-458.

5. Bhattacharjee, P.N., 1956. A genetic survey on the Rarhi Brahmin and the Muslim of West Bengal $\mathrm{A}_{1} \mathrm{~A}_{2} \mathrm{BO}$, $\mathrm{MN}$, Rh blood groups, ABH secretion, sickle cell, PTC taste, middle phalangeal hair and colourblindness. Bull. Anth. Surv. India, 5: 18-28.

6. Blakeslee A.F. 1931. Genetic of sensory thresholds: Taste for phenylthiocarbamide. Science; 74: 607. [PMC free article] [Pub. Med.]

7. Blakeslee A.F. 1932. Genetic of sensory thresholds: Taste for phenylthiocarbamide. Proceeding of the National Academy of science; 18: 20-130. [PMC free article] [Pub. Med.]

8. Cardullo H., Holt L. J. Ability of infants to taste PTC: its application in cases of doubtful paternity. Proceedings of the Society of Experimental Biology and Medicine.1951; 76: 589-592. [Pub Med]

9. Crow, J.F. and Dove W.F. 2006. Phenylthiocarbamide: A 75 year adventure in genetics and natural selection. Genetics. Vol. 172 No. 4, 2015-2023.

10. Das, P.B. and Ghosh, A.A. 1970. A study of ABO groups P.T.C. ear lobe attachment among the kumars of Assam. J. Assam Sci. Soc. 13: 14.

11. Das, S.R. 1956. A contribution of heredity of P.T.C. taste character, based on a study of 845 sib pairs. Ann. Hum. Genet., 20(4): 334-343.

12. Das, S.R. 1958. Inheritance of the P.T.C. taste character in man: An analysis of 121 Rarhi Brahmin families of West Bengal. Ann. Hum. Genetc., 22: 200-212.

13. Das, S.R. and Bhattacharjee, P.N. 1963. Blood groups $\left(\mathrm{A}_{1} \mathrm{~A}_{2} \mathrm{BO}\right)$, $\mathrm{ABH}$ secretion, sickle cell, $\mathrm{PTC}$ taste and colour blindness in the Rajbanshi of Midnapur district, West Bengal, Bull. Anth. Surv. India., 12: 1-6.

14. Das, S.R., Kumar, N., Bhattarjee, P.N. and Sastry, D.B. 1961. Blood groups (ABO, MN and Rh), ABH secretion, sickle cell, PTC taste and colour blindness in the Mahar of Nagpur. J. Roy. Anthrop. Inst., 91: 345355.

15. Forrai G., Bankovi G. Taste perception for phenythiocarbamide and food choice-a Hungarian twin study. Acta Physiologic a Hungarica. 1984; 64: 33-40. [Pub Med]

16. Fox A.L., 1932. The relationship between chemical constitution and taste. Proceedings of the National Academy of Sciences. 18: 115-120 [PMC free article] [Pub. Med.]

17. Guo S.W. \& Reed D.R. 2001 The Genetic of phenylthiocarbamide perception. Ann Hum Biol., Mar-Apr;28(2): 111-142

18. Harris, H. and H. Kalmus, 1949. The measurements of taste sensitivity to phenylthiourea (PTC). Ann. Hum. Gonat, 15: 24-31.

19. Hartmann G., 1939. Application of individual taste difference towards phenylthiocarbamide in genetic investigations. Annals of Eugenics; 9: 123-135.

20. Kalmus H. 1952. Inherited sense defects. Scientific American. 186: 64-70.

21. Kaplan AR, Glanville EV, Fischer R. Cumulative effect of age and smoking on taste sensitivity in males and females. Journal of Gerontology. 1965; 20: 334-337.

22. Laxmi, Y. and Kapoor A. K. 2011. A study of Taste Sensitivity of Phenylthiocarbamide (PTC) and Colour blindness among the Rajpoot of Dadra Nagar Haveli, Anthropologist 13 (2): 163-165.

23. Lee B.F. 1937. A genetic analysis of taste deficiency in the American Negro. Ohio. Journal of Science; 34: 337 342.

24. Martin NG. Phenylthiocarbamide tasting in a sample of twins. Annals of Human Genetics, London. 1975; 38 : 321-326. [Pub Med]

25. Matsunaga E., Tsuji T. individual differences in taste-ability for some chemical compounds. Japan Journal of Human Genetics.1957; 2: 79-80.

26. Merton B.B. Taste sensitivity to PTC in 60 Norwegian families with 176 children. Confirmation of the hypothesis of single gene inheritance. Acta Genetica et Statistica Medica.1958; 8: 114-128. [Pub Med]

27. Pons, J. 1960. A contribution to the heredity of the P.T.C. taste character. Annals of Human Genetics, London; 24: 71-76. [Pub Med] 
28. Rao D.C., Morton N.E., 1977. Residual family resemblance for PTC taste sensitivity. Human Genetics. 36 : 317-320. [Pub Med]

29. Srivastava, R.P. 19-59. Measurement of Taste Sensitivity to Phenyl-thio-carbamide (P.T.C.) in Uttar Pradesh. The East. Anthrop. 12(4): 267-772.

30. Whissell-Buechy D. Genetic basis of the phenylthiocarbamide polymorphism. Chemical Senses. 1990b; 15: 27 37. 